\title{
The Revitalization of Malay Sultanate Culture Arts through Mapping as an Asset for Tourism Development in North Sumatra
}

\author{
Yusnizar Heniwaty ${ }^{1}$, Muhammad Anggi Daulay ${ }^{2}$, Ika Purnamasari ${ }^{3}$ \\ ${ }_{1,2,3}$ Universitas Negeri Medan, Medan, Indonesia \\ yusnizarheni@yahoo.com
}

\begin{abstract}
Art and cultural products in Deli Serdang Regency, Batubara Regency, and Tanjung Balai City are inseparable from the Malay kingdom sites that were established at the time. The Malay kingdom was led by the sultan, usually marked by the establishment of the palace as a sign of the grandeur and sovereignty of the king and all his relatives, which then made the palace a place to live, consult, and decide on an event. In addition to the splendor of the palace, various arts and cultural products that became symbols of local wisdom became part of his time, but nowadays various art and cultural products are considered to have no maximum implementation and distribution to the younger generation as holders of cultural relay batons. So that these products are not extinct, they need the attention of the entire community, government, and stakeholders. One way to bring it back is to revitalize it by developing it into a tourist dish. This study aims to: Know the condition of art and culture, cultural potential, in the three regions of the Malay sultanate, and the efforts of the government, artists in revitalizing the potential of art and culture. The research method used is descriptive qualitative, with data collection in the form of, mapping, interviews, and observations. The results of the study explained that each of Serdang, Batubara, and Tanjungbalai Sultanates had potentials that could characterize their regions, there were: Serdang Sultanate with Makyong arts, Tanjungbalai Sultanate with Gubang arts, and Batubara Sultanate had the story and Lima Laras palace. These three potentials can be developed into cultural tourism attractions in the region and North Sumatra. This requires the creativity of artists in developing them from every aspect. Government intervention also becomes necessary in sustaining the existence of cultural arts by making policies that sustain the art and culture. In addition, for the cultural actors can develop professionalism in accordance with their field of expertise.
\end{abstract}

Keywords

Malay Sultanate, art and culture, revitalization; tourism

\section{Introduction}

Culture is a marker of regional identity possessed by every nation in Indonesia. Culture can also be said as a pattern of life that grows and continues to develop in the community to regulate each individual in speaking, behaving, and interacting with other individuals. Soemardjan and Soemardi in their book titled Society and Culture, argued that culture is all 
the work, taste, and creativity of the community. The work includes technology products and other materials, taste includes the human soul that is in harmony with social norms and values, while creativity includes cognitive and mental abilities to practice what he knows. In its implementation, there are several elements that make up culture or culture, including art which includes various forms of art, such as music, dance, painting, literature, architecture, and others. Every human creative work that contains art is a cultural element.

North Sumatra as one of the provinces that has cultural richness, is an area that holds a lot of potential excavation of cultural and artistic elements which in reality have been marginalized by the times, eroded by modernization, and indirectly began to be forgotten by the owner of that culture. This is certainly a point of weakness that has relevance to the icon of North Sumatra province as a province of culture and tourism. Talking about culture, of course related to the existence of tribes who inhabit the province. Malay is one of the native tribes of North Sumatra spread along the coast of the island of Sumatra. The fourth tribe with growth reaching 5.92\% under Batak, Javanese, and Nias tribes. Distribution of domicile of Malays in North Sumatra is located in Medan City, Deli Serdang Regency, Serdang Bedagai Regency, Batubara Regency, Tanjung Balai City, Labuhan Batu Regency, Tebingtinggi City, Asahan Regency and Langkat Regency.

Art and cultural products in Deli Serdang Regency, Batubara Regency, and Tanjung Balai City are inseparable from the Malay royal sites that were established in their time, with the form of a kingdom led by the sultan or the grandfather. Malay kingdoms are usually marked by the establishment of the palace as a sign of the grandeur and sovereignty of the king and all his relatives who then make the palace as a place to live, deliberate, to decide a hajad. Aside from being a meeting place, the kingdom is also a place for developing Malay cultural arts, so that in the sultanate's government, the kingdom becomes a cultural center.

Makyomg Art, Tetaer Nobles, Gubang, Didong singing, crafts, food, and the Palace, are cultural products that are the product of creativity from the interaction of the whole community (nobility, people) with their environment. The results of this creativity embody the pattern of life of the Malay community as outlined in the forms of symbols that have moral values and become guidelines / guidelines for the people.

Some of these cultural creativities have been reviewed by various analyzes, especially in art studies. Tomy (2015) in the S-2 study has examined gubang as a accompaniment to gubang dance as seen from the structure and function of gubang. This paper concludes that Gubang Art is presented always associated with traditional ceremonies and entertainment for the Malay community, functionally, gubang is presented in entertainment and ritual activities. In the gubang dance functions entertainment, musical accompaniment humming (didong) functioned as a ritual, because in the sea herbal medicine ceremony gubang music becomes the media in accelerating the arrival of supernatural beings in helping the process of gravity. Studies on Makyong have also been carried out both on Makyong from Malaysia (Hardy) and from Indonesia (Prudentia).

Potential features of Malay cultural arts are in the art form by making Islamic teachings a source of creativity. Ediwar (2014) explains the distribution of rapa 'art and strategic steps taken by artists, cultural figures and local governments to make rapa' art remain alive and sustainable after being hit by disaster. Rapa'i is an Islamic nuance of art in Aceh, laden with religious, cultural, social, beauty and educational values. Rapa'i is used as a medium for da'wah and acculturation with local culture. Expressive symbols of art and religion fuse into the power of Islamic cultural and religious spirituality. The elements of art in the form of music, dance and literature become separate characters and have delivered rapa'i art as 
Aceh's cultural identity. This is in line with Malay cultural art which is loaded with Islamic values, so that Malay cultural arts are also based on customs based on Islamic teachings. These forms of art and culture are then utilized in the context of tourism.

Utilization here includes efforts to use cultural products for various purposes, such as to strengthen the image of regional identity, for cultural awareness education, to become a cultural industry load, and to be used as a tourist attraction. Thus, the utilization of cultural products through tourism development is one step to keep the culture and its products sustainable (Edi Sedyawati, 2004: 76).

The revitalization of Malay sultanate art in the form of mapping the potential of art and culture is one part of the effort to preserve traditional arts. Revitalization is an effort to "vital" or revive something whose existence is still meaningful and thus the existence needs to be maintained and developed (Soedarsono, 2010: 2) Revitalization can mean processes, ways, and actions to revive or activate various any program of activities, or more clearly revitalization is to revive vitality, Alwi (2007: 954). The revitalization of the Malay sultanate's cultural arts was intended to explore and revive the cultural arts, by preserving their original form and developing it while still adhering to the existing format. Therefore, this study tries to uncover about: (1) What are the conditions and potential of Malay sultanate's cultural arts and culture in North Sumatra? as an asset in the world of tourism, (2) What are the efforts of the government, the sultanate, artists and tourism practitioners in revitalizing the potential of art and culture?

In line with the problems to be revealed, this research applies a qualitative research model and data collection is carried out through observation, in-depth interviews, use of archives (documents) and library sources. The data obtained were then analyzed using the interaction analysis model.

\section{Review of Literature}

\subsection{The Diversity of Malay Sultanate Cultural}

Referring to Johan Anderson's account in 1823, explaining the position of the sultanate was made as a cultural center, as in the Serdang Sultanate which began at the time of the Sultan Thaf Sinar Basar Syah government. As cultural centers, each empire and empire owns and develops various expressions of art, culture, language structure, literature, building styles, customs, family systems, social ethics, culinary delights, household appliances, clothing designs, religious culture, etc. These various types and elements of culture were developed massively into various cities and villages that became their territory, and then became local cultural identities that were of high value and were worth preserving. Some art and culture that are still included as cultural attractions that can be developed, as a tourist attraction and become a major asset through cultural arts are divided into several aspects, namely:

\section{a. The Sultanate of Serdang}

1) In Sultanate of Serdang there is a replica of the Serdang Palace on Jalan Lintas Sumatra. The establishment of this replica was initiated by Sutan Lukcman SInar Basarsyah II, based on the old Palace named Darul Arif Palace, inaugurated on January 7, 2012. Today it is now one of the icons of Serdang Bedagai Regency, located in the city of Galuh, Perbaungan Sub-district, Serdang Bedagai Regency. The Darul Arif Palace was founded on 29 July 1889 built by Sultan Sulaiman Shariful 
Alamsah, the fifth king of the Serdang sultanate lineage. The territory of the Sultanate of Serdang itself includes Batang Kuis, Padang, Bedagai, Percut, Senembah, Araskabu and Romania. Then enter the Perbaungan area because of the marriage ties.

2) Makyong theater: Makyong is a traditional dance drama from a society that is of the same culture (Malay family), namely the Nara Pala region, Patani around the 17th century, then spread to the Kelantan region (around 200 years ago) Pudentia (2000), citing Shepppard's opinion. In its presentation Makyong combines elements of ritual, dance, singing, and music, and brings the players and audience together. In other words, the audience could be involved in the performance, and the players would wear masks if they were acted by men on the part of the King, Princess, villain, villain, devil and spirit characters, just as they were performed at Nara Yala. "Mak Yong" or "Makyung" is still staged to this day, although the quantity of the show can be counted on the fingers. Sultanate of Serdang as the successor of this art, until now still perform it, although not as often as in the empire's era is still there. They took steps to maintain Mak Yong by staging it in various event activities such as including performances funded by the Yayasan Manage in performances in three venues (Perbaungan, Langkat, Medan) in 2006, PRSU in 2004, Pedati (Bukit Tinggi Cultural Festival) in 2007, Pekan Jakarta Indonesia Creative Products in 2009, and so on. In addition to the Sultanate of Serdang, currently the Performing Arts Study Program also includes Makyong as material in Malay practice courses (dance, music, and theater).

3) Theater of the Nobility: the mention of the Theater of the nobility was originally called a royal play or aristocratic opera, this art is a form of performance in the past, specifically staged before the kings, empresses, and other royal families. Likewise, the audience which also consisted of nobles and invited by the king to jointly scrutinize the show, so that this drama is called a "royal play" or opera nobility, royal drama, and the theater of the nobility. The story played is usually the story of 1001 Nights, Malay People, Indian and Chinese Fairy Tales. While the accompanying songs are usually dance or Zapin songs, the songs "Stambul Dua", "Stambul Opera", and "Dendang Sayang" or "Selendang Delima". Each story is divided into several acts or scenes, interspersed with time intervals to tell what will happen in the next scene. This is done as an introduction so that the audience knows the next scene.

\section{b. The Sultanate of Tanjungbalai}

1) The city of Tanjungbalai as the sultanate of Asahan, originated from the Journey of the Sultan of Aceh, Sultan Iskandar Muda, to Johor and Melaka in 1612. On their way they rested in the upper reaches of the Asahan River, which then set up a place to rest and set up a courtyard as a hall for a place to face. Over time this place developed into a village called Tanjungbalai, and eventually developed into the Asahan Sultanate in the sixteenth century, with the crowning of Sultan Abdul Jalil as Sultan Abdul Jalil Rahmat Syah as the first Sultan Asahan. The coronation of the king on December 27, 1962 was then determined to be the "Anniversary of the City of Tanjungbalai" based on the decree of the DPRD of Tanjungbalai City Number: 4 / DPRD / TB / 1986 on November 25, 1986. On this anniversary, it is usually celebrated with a party that plays a variety of arts and Tanjungbalai culture. 
2) The people of Tanjungbalai, although they have heterogeneous ethnic groups, they still hold strong Malay cultural traditions, which do not carry out their traditional events. Inclusion of fresh flour, hall, betel nut, used in the event of marriage, marriage ceremonies, and the imposition of children (aqiqah). In addition to these three Malay elements, in every traditional event, they also include arts such as dance, music as entertainment, Qasidah, Bordah, Hadrah, dances, which are very thick with Islamic elements.

3) Gubang Art: Gubang is art that consists of music, dance, and rhymes performed in an expression of excitement as a form of gratitude from the realization of desires that can be a means of interaction between humans, relationships with God, relationships with other creatures. It is believed the inclusion of gubang can express all desires. Gubang art is also known as gubang dance and gubang music as well as being an icon of the City of Tanjungbalai exhibited as entertainment, as well as traditional activities as offerings, honors.

4) Didong and humming songs are typical songs of Tanjungbalai which is also a musical accompaniment in gubang dance which forms the basis for creating Gubang art. This is because, this song shows the interaction between humans and the creator. Through poetry that is sung, poured out submission, sincerity, patience, petition and deep gratitude for the hopes and desires they convey can be realized. In addition, there is also a story about Simardan Island.

5) The story of Si Mardan is one of Asahan's original folklore. This saga tells the story of a young man overseas from the Batak land (Porsea) who pitted his fortune in the Malay land of Asahan. This story is believed to be set in one of the village in the Tanjungbalai City now known as Pulo Simardan Village. Broadly speaking the same as the Malinkundang Legend in West Sumatra and Sampuraga in South Tapanuli. These folktales contain values about the honesty, responsibility and obligation of a child to respect and love his mother, parents. Until now this saga is considered as one of the icons of Asahan Sultanate's literature. The Mardan saga contains a load of high moral values. Values that are currently considered important to be internalized in the younger generation / millennial.

\section{Discussion}

\subsection{Accessibility and Amenities}

The development of tourism which has become foreign exchange outside oil and gas, is now the belle of oil and gas substitutes which have been promoted since the 1990s. This of course requires collaboration from all stakeholders to be able to jointly develop it. One of the important points is the existence of tourism accessibility.

Tourism accessibility in the Malay sultanate, to get to the leading tourist objects is easily achieved, in the form of procurement of road infrastructure, public transportation, as well as signs towards tourist attractions. Making it easier for people to be able to visit, and see a variety of cultural potential possessed, as well as bring in foreign exchange for the region. Although overall, there are still some accesses that are difficult to reach, and pass through. This of course requires the role of local governments to jointly overcome this problem. In addition to supporting the tourism industry, the need for facilities and infrastructure has also become very important, including tourism services as a connector between cultural actors and visitors. In the imperial area in Deli Serdang Regency, 
Serdang Bedagai Regency, Tanjungbalai City already has information centers from all aspects which are sufficient to support tourism, as well as reintroducing Malay cultural arts.

\subsection{The Actual Conditions of Malay Sultanate Cultural Diversity}

The potential of cultural diversity in the Malay Sultanate region has now begun to be forgotten, and some have been developed by making it a basis in the creation of various art forms. Makyong Art, Gubang as a Malay cultural heritage which is quite famous in its era, is now starting to be brought back. With the efforts of the descendants of the Serdang sultanate, who collaborated with various agencies to re-emerge their art, it had a positive impact. The development of this art began to be raised, in various art events, one of them the district government. Deli Serdang held a Cultural Night which was followed by art groups in various ethnic groups, one of which was the performance of Makyong and the Bangsawan Theater.

Tanjungbalai City with a feast of feathers on the birthday celebration Tanjungbalai City also helped revive the art of gubang in its performances including holding a gubang dance contest with the appearance of various forms of gubang dance, but still in the existing format. With celebrations that carry Malay culture, cultural arts groups have also emerged, both those managed by the community, and those that have emerged from schools. But not all arts and cultural associations can be said to be directed with a permanent organization. This is due to obstacles in the procurement of facilities and infrastructure to support its existence, which requires no small amount of funds, in addition to cultural activities that are not regularly scheduled.

The regional government in this case has been striving to maintain the continuity of the existing cultural arts groups, by making cultural arts events that seek to familiarize themselves with their owners. However, in its implementation it has not been able to foster public appreciation to see, maintain, and pass it on. This is possible because there is monotony in the presentation, so creativity is needed to develop according to the times. Positive things from the implementation of cultural events, there is still a lot of participation from the people who crave the preservation and development of Malay cultural arts, which are not only desired from the imperial family. The general public, students, and young people are actively involved in carrying out the inheritance of Malay cultural arts. Participate in various festivals held by the government and institutions, and incorporate cultural arts material in events for the benefit of individuals and groups. Besides that, Malay cultural arts are not only favored by Malays, but other tribes make Malay culture as their own. This effort has a pretty good impact, with the emergence of studios that teach Malay cultural arts (dance) as a basis for dancing ability. In addition, in literature, the "telangkai" revival is starting to appear, in addition to dance offerings at the beginning of the event, and a face-to-face meal program that presents a variety of typical Malay culinary. Furthermore, the schools also provide Malay material in the learning of Malay cultural arts, both in formal activities and as extracurricular activities.

The development of Malay culture and art is not only done in terms of quantity, but also the quality aspect is important to do. Malay cultural festivals held in several districts in the Malay sultanate region, presenting various competitions (dance, pantun, Malay style, Malay culinary) in it, became awaited event by all circles. So that the quality aspect is increasingly needed to maintain the originality of art and culture, which at the same time are also able to develop it by not eliminating its tradition. In fact the creativity of traditional 
culture will add to the treasury of Malay cultural arts, which in turn enriches the cultural arts they possess.

The active Malay cultural arts also have a great impact on the community, because these events will provide income to them through services as dancers, musicians, telangkai and others. The problem that arises, is the lack of ability to work on art, so that the resulting creativity has not been able to generate income as expected, in addition to competition between groups in determining the funds received. So that readiness is needed in managing it to give satisfaction to the audience / connoisseurs, and attract more viewers, and maintain price differences. Besides that assistance to the artists is very necessary, so they want to show it and pass it down, and can develop it with their creativity. Thus it can be assured that through the ability in cultural arts, can provide income for them.

\subsection{The Revitalization of Malay Culture Potentials in the Development of Tourism in North Sumatra}

Sultanate of Malay culture and art can be used as an icon (attraction) of tourism in each district, with its strengthened characteristics. This requires the involvement of all components of society, such as artists, government, tourism practitioners, and academics to jointly preserve, develop, and maintain. The tourism office as a fully authorized government agency will require design and strategy in realizing Malay culture and art by choosing arts (literature, music, dance, visuals) as icons of the region.

The tourism office in the Malay Sultanate region actually has arranged the development of cultural arts as a characteristic of its area, such as:

1) Feast of Malay Culture by presenting a variety of Malay cultural arts, workshops, seminars for the introduction and strengthening of Malay cultural arts to owners and connoisseurs. 2) Increase the insight, creativity of artists through the appointment of Malay traditional arts. 3) The local government facilitates Malay arts performances and festivals, in the event of national holidays, regional birthdays, and special events of Malay culture. 4) The Culture and Tourism Office motivates and provides facilities for artists who want to practice improving their skills. 5) Organizing a Festival of Malay cultural arts at the district level, to the province.

In revitalizing Malay cultural arts, efforts are needed to strengthen regional identity through the development of tourism, including: (1) packaging of Malay cultural arts for the context of tourism as cultural attractions, by promoting the values of local wisdom, (2) the diversity of cultural arts attractions provided in various attractions as attractions, (3) improving the quality of cultural arts performances by involving universities that have the field of cultural arts, (4) maintaining and developing a variety of Malay cultural arts in various forms of performance. (5) making and reviving the arts building as a center for arts and culture, (6) publications in mass media both electronic and print, as a medium for the delivery and delivery of information that can be accessed quickly, (8) promotion of culture through performances in events that are include other ethnicities and other regions and countries.

\section{Conclusion}

Sultanate of Malay in North Sumatra, bequeathed cultural arts which have values and can be used as tourism assets. The existence of such art and culture still exists today, it can be seen from the implementation that is still carried out by the community in various activities. 
The forms of Malay cultural arts (literature, dance, music, appearance) have a positive impact both for actors, connoisseurs, and for the government.

The tourism office has made efforts to preserve, bequeath, and conserve Malay cultural arts in various events to introduce and familiarize the community. This effort is made to attract interest not only for the owner, but for other ethnic groups, which can be used as learning in seeing a group of people. In the presentation, it is necessary to have skills in honing creativity, to make art and culture attractive, but its development remains within the corridor of the traditional. So we need the role of other institutions in assisting its development.

\section{References}

Alwi, Hasan. 2007. Kamus Besar Bahasa Indonesia. Jakarta: Pusat Bahasa Departemen Pendidikan Nasional.

Bagas, Arwansyah Anuar. 2017. "Revitalisasi Peran Budaya Lokal Dalam Materi Pembelajaran Bahasa Indonesia Bagi Penutur Asing (Bipa)" Proceding The 1st Education and Language International Conference Proceedings Center for International Language Development of Unissula . Surakarta

Barus Mipika, Tomi. 2015. "Sruktur dan Fungsi Seni Gubang dalam Kebudayaan Masyarakat Melayu Tanjungbalai” Tesis S-2 Universitas Sumatera Utara.

Ediwar. "Rekonstruksi dan Revitalisasi kesenian Rapa'i Aceh Pasca Tsunami” Jurnal Recital, Vol 17 No 1 April. 2016 hal 30-45

Pranata, M. 2010. Teori Multimedia Intruksional, Malang, Universitas Negeri Malang dan Bayu Media Publisihing.

Soedarsono, RM. 2010. Seni Pertunjukan di Era Globalisasi. Yogyakarta: Gadjah Mada University Press 